\title{
Evaluación de los aprendizajes en la formación de profesorado: tres casos y una problemática en común ${ }^{*}$ Raquel Bedetti, Josefina Ganuza y Eliana López
}

\author{
Palabras clave: \\ educación superior · evaluación de los aprendizajes . \\ aprendizaje significativo
}

Resumen. El siguiente artículo propone una mirada reflexiva sobre las propias prácticas evaluativas en la formación del profesorado, en la ciudad de Santa Fe, en tres espacios curriculares y ámbitos distintos: en la cátedra de Guitarra Armónica Aplicada, del Profesorado de Música del Instituto Superior de Música (FHUC, $\mathrm{UNL}$ ), en las cátedras Lengua y Literatura y su Didáctica, en los Profesorados de Nivel Inicial y Especial para Discapacitados Intelectuales, del ISPI Dra. Sara Faisal, y en las cátedras Ciencias Sociales y su Didáctica en los Profesorados de Nivel Inicial y de Educación Primaria en el ISPI San José de Adoratrices.

Las autoras nos centramos en una misma concepción acerca de la evaluación, desde la práctica situada y la participación entre los sujetos en relación implicados (docentes y estudiantes) y nos preguntamos acerca de la evaluación de la construcción del conocimiento en la relación entre las instancias de evaluación parciales y el examen final.

\section{Keywords:}

graduate level education - evaluation of the learning process $\cdot$ meaningful learning

Abstract. The following paper contains reflections on the evaluation process during the formative stages of the Teaching Training Courses in Santa Fe city, in three distinct institutions and in different carrers: Applied Guitar Harmonics in the Music Teaching Course of Instituto Superior de Música (FHUC, UNL), Language and Literature and its Pedagogy in the Teching Courses of Initial Level and the Special Level for the Intellectually Impaired of ISPI Dra. Sara Faisal, and Social Sciences and its Pedagogy in the Teaching Course of Initial Level and Elementary School of ISPI San José de Adoratrices.

The authors focus on a single conception refered to evaluation taking as a starting point the located practice and the participation between the engaged subjects (teachers and students) and question about the evaluation of knowledge construction in the established conections between term exams and final exams.
(*) El presente trabajo fue producido para el Seminario de Posgrado «Evaluación de los aprendizajes», dictado y corregido por la Lic.
Susana Celman, en el marco de la Maestría en Didácticas Específicas de la FHUC, UNL. 